\title{
Learning Models in English
}

Solomon Zulu ${ }^{1}$, Gampani Phiri ${ }^{1}$

${ }^{1}$ Department of Primary Education, University of Zambia, Zambia

*Corresponding Author: Solomon Zulu

Received: October 28, 2020

Revised: November 12, 2020

Accepted: November 18, 2020

\begin{abstract}
The aims of this paper are know the definition, competence and the procedures of each learning models in English. The learning process at school is an educational process that is planned, integrated, and systematical coordinated with clear and firm evaluation standards and measures. By therefore, everything related to the process learning in schools is an interpreted whole cannot be separate and random. A curriculum there must be systematically connected with the methodology learning is used, while the methodology the lesson must also be formulated in details and details. Therefore, curriculum development on practice is always bound and is strongly connected with learning methodology.
\end{abstract}

Keywords: Learning, Model, Curriculum, Methodology

\section{Introduction}

According to Fantili \& Mcdougall (2009) most problems faced by the education system in the world led to these two main problems, namely curriculum and learning methodology. Curriculum function as a compass in the sense of determining the direction of the road learning process that will be used. Meanwhile, learning methodology is the cutting edge. Curriculum it might not work properly if not followed by systems and systematics learning method and integrated. In terms of material, curriculum concepts are developing at the moment this is considered sufficient to become a standard of learning at school at least for the time being. This is not same as the learning method used. Learning method that are developed and developed in schools in general are conventional and classic (Knowles et al., 2014). Namely, the teacher tells stories, students listen and take notes. The teacher gives, the students receives. Such a concept is indeed not wrong nor is it bad. It's just that it tends to be slower in forming knowledge in students. Students are only considered containers blank that must be filled in with the appropriated color and color characteristics of the teacher. As a result technological progress and science that developed in the Asia became slower and lagging behind other countries.

\section{Role play}

Role play according to (Nestel \& Tierney 2007) is a language learning technique that asks students to play a certain role in a given situation, using the target language, ie the language being studied (such as English, for example). To practice expressing complaints and apologies in

DOI:

Copyright (C) 2020, Journal Educational Verkenning, Under the license CC BY-SA 4.0 | 14 
English, for example, students play the role of buyer and seller in a shop. The buyer returns the goods he has bought from the store because the item is damaged. Competencies developed, language skills that can be developed with role play are speaking, especially interpersonal and transactional dialogues. Procedure, (1) Inviting students to identify situations for role play, such as whether role play will be held between teacher and student, doctor and patient, or hotel guests with recipes (2) Inviting students to design role play, such as whether role play is structured, semi-structured, or free. Also, whether the role play will be carried out by two people, three people, or more. (3) Facilitating students to identify the language function that is expected to appear in conversation / role play. (4) Inviting students to identify language forms for each language function. (5) Directing students to drill a number of identified language forms. (6) Facilitating students to do role play exercises in small groups. (7) Facilitating students to perform role play in front of the class. (8) Invite students to evaluate the results of student performance.

\section{Process Approach}

Kuhlthau (2004) defines process approach as method of language learning, especially writing, which gives students the opportunity to experience, appreciate, assess, and reflect on the steps of writing a text, from planning to writing the end of the text. Here the focus is on the process of writing, not the results of writing. (1) Competencies developed, Language skills developed with this process approach are writing, especially free writing. (2) Procedure, (1) Planning. At this stage the teacher guides students to select and determine topics, limit topics, and write topic sentences or theses. (2) Outlining. At this stage the teacher asks students to write pointers for the contents of information that can develop the topic. (3) Drafting. At this stage the teacher facilitates students to develop every pointer of information into sentences or paragraphs. (4) Revising / Editing. At this stage the teacher asks students to assess the draft they have made, then make revisions or editing so that the draft is better. Revisions include content, organization, grammar, vocabulary, spelling, and so on. (5) Rewriting. At this stage the teacher asks students to rewrite the revised draft. This becomes the product or student's final writing.

\section{Inquiry-based Teaching}

according to Furtak et al. (2012), it is a learning method that involves students intensively to raise questions or problems, submit hypotheses, conduct observations or investigations, analyze data, and draw conclusions, and explain their findings to others. The expected answers to these questions are not singular but plural. What is important is that in searching for answers, students work using certain clear procedures and standards so that the results can be accounted for. Therefore, it is possible for them to integrate and synergize various methods and different scientific disciplines. Competencies that can be developed by IBT are all language skills and language elements. Procedure: (1) Asking. Students ask questions or problems related to the topic being studied. (2) Investigating. Students conduct investigations with various techniques such as observation, interviews, or document analysis to gather information relevant to the questions that have been asked. (3) Creating. Based on the results of investigations students construct new knowledge that is different from previous knowledge. (4) Discussing. Students convey their findings (new knowledge) to their classmates, and compare whether the knowledge

DOI:

Copyright (C) 2020, Journal Educational Verkenning, Under the license CC BY-SA 4.0 
they construct is the same or different from other peers. (5) Reflecting. After the discussion is over, students have the opportunity to reflect on what has been done and found.

\section{Discussion method}

Based on Campbel et al. (2008), is a learning method that involves students or groups of students intensively to conduct scientific talks to gather opinions on a problem, then make conclusions or arrange alternative solutions to the problem. Competencies developed, competencies that can be developed by the discussion method are all language skills and language elements. Procedure: (1) The teacher raises the problem to be discussed and gives direction as needed on how to solve it. (2) Students form discussion groups, elect a chairperson, a secretary, and if necessary also a group spokesperson. (3) Students conduct discussions in their respective groups actively, democratically, and respect each other; meanwhile, the teacher goes around between discussion groups to ensure that all groups work well. (4) Each group (through its spokesperson) reports the results of the discussion, which is then responded to by other groups. (5) Teachers and students evaluate and reflect on the process and results of discussions to get the best results. (6) Each group collects reports on the results of their discussions (the results of group discussions that have been given input by other groups and teachers), to be assessed or used as archives of class activities.

\section{Problem-based Learning}

based on Savery ( 2015), it a learning method based on problems in real life. Students are asked and guided to learn the problem based on the knowledge and experience they have had before so that new knowledge will form. Competencies developed, competencies that can be developed through PBL are all language skills and language elements. Procedure: (1) The teacher introduces students to the problem, or the problem is identified and determined jointly between the teacher and student. (2) The teacher organizes the implementation of learning, for example whether students work individually, in pairs, or in small groups. (3) The teacher guides students to carry out investigations in relevant ways, such as whether it can only be through library research, trials, or arrive at experiments. (4) The teacher facilitates students to present the results of their investigations in front of classmates for later response. (5) With the guidance of the teacher students analyze and evaluate the problem solving process and the results of investigations that are achieved. (6) Students make written reports in an agreed format, to be graded by the teacher or to archive class activities.

\section{Games}

It is stated by Karaaslan et al. (2018) that games are activities that have rules, goals and elements of fun. Within the scope of learning English as a foreign language, there are two types of games, namely communicative games which are distinguished from linguistic types of games. Games can also be divided into competitive games and cooperative games. In addition to being fun, communicative games have the potential to create communication activities. Competencies developed, usually communicative games are used to develop speaking skills, whereas linguistic games can be used to develop mastery of language aspects such as vocabulary and grammar. Described below are only communicative types of games. Procedure: Pre. Games: (1) Explain the

DOI:

Copyright (C) 2020, Journal Educational Verkenning, Under the license CC BY-SA 4.0 | 16 
skills and competencies to be developed. (2) Conduct discussion and drilling about vocabulary and expressions that will be used in the game. (3) Explain the game procedure. (4) Give examples of game implementation. Games: This stage is used to carry out the game. Post-Games:This stage is used to provide input related to student errors recorded by the teacher.

\section{Jigsaw}

according to Stasco \& Liu (2008), it is a form of cooperative learning, which is interpreted as learning that creates meaningful classroom interaction in a supportive environment so that it leads to better learning achievement, increased student motivation to learn, and overall to changes in psychological conditions of students. Competencies developed, jigsaw can be used for developing listening or reading and listening skills together. Procedure, the following learning steps for listening and reading learning: Listening: (1) The teacher plays a recording in which three people with different opinions discuss their opinions on a topic. (2) The teacher prepares three tasks, each task focuses on one of the three different opinions earlier. (3) Students are then divided into three groups $A, B$, and $C$ and each group listens to the recording while working on the prepared task and which is focused on one different opinion. (4) The student group is then reorganized into groups consisting of one different student from groups A, B, and C. (5) The new group then plays a role discussing the same topic using the information they have gotten from the listening activity. (6) The teacher provides input on student performance. Reading and listening: (1) The teacher takes the narrative written text and cuts it into sections according to the number of students. (2) Every student gets one part of the story. (3) After reading the section, students then walk around the classroom and while listening to every part of the text that is read aloud by other friends. (4) While listening to parts of the text that other friends read, students determine the position of their parts in the story. (5) Finally students must arrange in order the parts mentioned earlier into a complete text.

\section{Split Information}

Livingston \& Zhou (2010) define this activity as one form of many communicative activities. Nation (1988) refers to it as information gap activities. This learning activity involves at least one student who has information and the other students don't have it but need it. To get this information students who do not have it must communicate in a certain form. Competencies developed, the skills that can be developed with this activity are speaking skills. Procedure: (1) The teacher determines the competencies and topics to be developed, for example describing shapes such as circles, triangles, lines, rectangles and object positions. (2) The teacher prepares two sheets of paper with similar drawings, for example one containing a number of twodimensional shapes in a certain position, and the other paper containing pictures of the same dimensions but having different positions. (3) The teacher divides students into pairs, each student gets a different picture from the picture of his partner. (4) The teacher explains the procedure of activities where each pair must ask questions from each other to find differences and similarities. (5) The teacher gives an example. (6) After finishing one of the members of the couple is asked to report the results of the question and answer. (7) The teacher discusses and provides input regarding students' mistakes. Note: if necessary (depending on the level of

DOI:

Copyright (C) 2020, Journal Educational Verkenning, Under the license CC BY-SA 4.0 
student competency and readiness), the teacher can make an introduction to the related vocabulary and its meaning and pronunciation.

\section{Problem Solving}

based on Hasani (2016), this learning activity is also one form of communicative learning activities where students are asked to solve a problem in groups. To solve this problem students must use language resources (languge resources) to communicate with each other. Competencies developed, problem solving is usually used to develop speaking activities and is very possible to combine it with other communication activities such as writing, listening and reading (integrated). Procedure. here are the steps to learning the problem solving method (1) The teacher determines the competencies to be developed. (2) The teacher determines the problems that will be solved by students. For example, how to choose the number of items available in the order in which they are used to save themselves from emergencies. This situation can be used to develop the ability to express and respond to opinions, approvals and disagreements. (3) The teacher explains to students the purpose and procedure of the activity. (4) If deemed necessary the teacher explains the necessary vocabulary and expressions and conducts drilling. (5) The teacher divides students into groups and each group is asked to discuss the problem and determine group choices. (6) After finishing the teacher asks each group to report the results of the group discussion in class discussion. (7) The teacher provides comments and input on the results of the discussion.

\section{Number Heads Together}

Jarvinen \& Poikela (2001) suggest this learning activity is a form of cooperative learning activities. The technique developed by Spencer Kagan (1992) is communicative because it provides an opportunity for students to share ideas and consider the most appropriate answers. In addition, this technique also encourages students to increase their cooperation spirit. Competencies developed, the skills that can be developed with number heads together are reading and listening. Procedure, the following are examples of learning steps for developing reading skills: (1) The teacher sets the competencies to be developed and appropriate reading material. (2) Students are divided into groups. Each student in each group gets an order number. (3) The teacher shares the text with the assignment related to competence and each group works on it. (4) The group decides which answer is considered the most correct and ensures each group member knows this answer. (5) The teacher calls one of the student numbers with the number called to report the results of their cooperation. (6) Responses from other groups. (7) The Numbered Head technique can also be continued to change the usual group composition and join with other students with the same number from other groups.

\section{Project-based Learning}

Mills \& Treagust (2003) defines it as learning that involves individual or group projects that are carried out within a certain period. The results of this project will then be displayed or presented to the class. Project-based learning is student-centered and communicative because students must communicate as part of completing this project. Besides that, this kind of learning is very contextual and also develops student soft skills. Competencies developed, basically this project-

DOI:

Copyright (C) 2020, Journal Educational Verkenning, Under the license CC BY-SA 4.0 
based learning can be used to develop one or more language skills in an integrated manner. Even this method can be used to teach vocabulary. Procedure, following are examples of integrated project-based learning steps with a focus on developing vocabulary developed with speaking skills. (1) The teacher determines the competencies to be developed. (2) The teacher explains to the students the types of vocabulary that will be developed, for example, prepositional phrasal verbs such as go up, look for, and take away. (3) The teacher explains the prepotional phrasal verbs patterns, meanings and examples of their use in sentences. (4) The teacher explains the projects that students must work individually, for example, as homework looking for two prepositional phrasal verbs with examples of their use in sentences whose results will be presented in front of the class. (5) Students present the results of their projects in front of the class. (6) The teacher divides students into pairs and each pair must arrange together a written conversation using prepositional phrasal verbs that has been presented. (7) Each pair demonstrates the conversation that has been arranged in front of the class. (8) Classically the teacher gives input on the presentation and demonstration of students' conversations.

\section{Task-based Learning}

Nunan (2006) defines this as a assignments here are defined as work made in such a way by the teacher to be done by students, and in completing these assignments students must use language resources (language resources) to communicate. Task-based learning has several main advantages: (1) able to create opportunities for students to communicate naturally in the classroom. (2) more emphasis on meaning rather than linguistic form, and therefore. (3) more able to foster motivation to learn because it is centered on students.

Richards (2002) states that Task-based learning can be used as the only framework, or only as one component in teaching English, and besides that, tasks can be used as teaching techniques or methods. In the elementary and secondary school curriculum in Indonesia this task-based learning refers more to technique or method. Competencies developed, basically all language skills can be developed with task-based learning. We can develop all skills in an integrated manner with a focus on one skill. In the context of the Communicative Approach the development of language skills with task-based learning is more precisely carried out in an integrated manner. Procedure, the learning step in task-based learning is divided into the preassignment stage, the assignment stage, and the post-assignment stage. Pre-assignment phase: (1) The teacher determines the competencies to be developed and chooses the appropriate type of task. For example, the competency to be developed is to describe the place (speaking skills) and the task is to design the two dimensions of the ideal home layout. (2) The teacher explains to students the competencies and assignments they will be working on. (3) If needed, the teacher explains and drilling task language components such as vocabulary, expressions and sentence structure. (4) The teacher gives a model of how the task is carried out. (5) The teacher divides the class into groups as needed.

\section{Conclusion}

There are 12 learning models in English which is Role Play, Process Approach, Inquiry Based Learning, Problem Based Learning, Discussion, Jigsaw. Split Information, Gmaes,, Problem

DOI:

Copyright (C) 2020, Journal Educational Verkenning, Under the license CC BY-SA 4.0 19 
Solving, Number Heads Together, Project Based Learning and Task Based Learning. These models learning are commonly used in daily for teaching programs in English.

\section{References}

Campbell, M., Gibson, W., Hall, A., Richards, D., \& Callery, P. (2008). Online vs. face-to-face discussion in a web-based research methods course for postgraduate nursing students: $A$ quasi-experimental study. International Journal of Nursing Studies, 45(5), 750-759.

Fantilli, R. D., \& McDougall, D. E. (2009). A study of novice teachers: Challenges and supports in the first years. Teaching and teacher education, 25(6), 814-825.

Furtak, E. M., Seidel, T., Iverson, H., \& Briggs, D. C. (2012). Experimental and quasi-experimental studies of inquiry-based science teaching: A meta-analysis. Review of educational research, 82(3), 300-329.

Hasani, A. (2016). Enhancing Argumentative Writing Skill through Contextual Teaching and Learning. Educational Research and Reviews, 11(16), 1573-1578.

Järvinen, A., \& Poikela, E. (2001). Modelling reflective and contextual learning at work. Journal of workplace learning.

Karaaslan, H., Kilic, N., Guven-Yalcin, G., \& Gullu, A. (2018). Students' Reflections on Vocabulary Learning through Synchronous and Asynchronous Games and Activities. Turkish Online Journal of Distance Education, 19(3), 53-70.

Knowles, M. S., Holton III, E. F., \& Swanson, R. A. (2014). The adult learner: The definitive classic in adult education and human resource development. Routledge.

Kuhlthau, C. C. (2004). Seeking meaning: A process approach to library and information services (Vol. 2). Westport, CT: Libraries Unlimited.

Livingston, M., \& Zhou, L. (2010). Split bond ratings and information opacity premiums. Financial Management, 39(2), 515-532.

Mills, J. E., \& Treagust, D. F. (2003). Engineering education-Is problem-based or project-based learning the answer. Australasian journal of engineering education, 3(2), 2-16.

Nestel, D., \& Tierney, T. (2007). Role-play for medical students learning about communication: guidelines for maximising benefits. BMC medical education, 7(1), 1-9.

Nunan, D. (2006). Task-based language teaching in the Asia context: Defining'task'. Asian EFL journal, 8(3).

Savery, J. R. (2015). Overview of problem-based learning: Definitions and distinctions. Essential readings in problem-based learning: Exploring and extending the legacy of Howard $\mathrm{S}$. Barrows, 9, 5-15.

Stasko, J., Görg, C., \& Liu, Z. (2008). Jigsaw: supporting investigative analysis through interactive visualization. Information visualization, 7(2), 118-132.

DOI:

Copyright (C) 2020, Journal Educational Verkenning, Under the license CC BY-SA 4.0 